\title{
Horizontal Conflict Resolution Model in Bima Society
}

\author{
R Ridwan* \\ Law Study Program \\ Sekolah Tinggi Ilmu Hukum Muhammadiyah Bima \\ Bima, Indonesia \\ ridwan@stihm-bima.ac.id \\ Taufik Firmanto \\ Law Study Program \\ Sekolah Tinggi Ilmu Hukum Muhammadiyah Bima \\ Bima, Indonesia
}

\author{
A Ahmad \\ Law Study Program \\ Sekolah Tinggi Ilmu Hukum Muhammadiyah Bima \\ Bima, Indonesia \\ M Mustakim \\ Law Study Program \\ Sekolah Tinggi Ilmu Hukum Muhammadiyah Bima \\ Bima, Indonesia
}

\begin{abstract}
The horizontal conflict in Bima West Nusa Tenggara has entered at a very worrying level in which it has a negative impact in the form of loss to the community property, obstruction of economic, social, educational, and psychological activities, and even casualties. This research is hoped to give a Horizontal Conflict Resolution Model for the Bima community. This is an empirical legal research using conceptual, case and statutory approaches. Primary data were obtained thorough indepth interviews with the victims of conflict and other informants, namely academics and community leaders who have concerns about the conflicts. Secondary data were obtained from research libraries on statutory regulations, books, journals, dictionaries, encyclopedias, and others. Further, the obtained data were analyzed through some stages, i.e., heuristics, verification, analysis, descriptive and prescriptive interpretation. The results of the research provide an overview in the form of descriptive data about the horizontal conflict phenomenon in the Bima community, including the causes of conflict, patterns and characteristics of conflict. This research also proposes a conceptual model of conflict resolution that can be used as a guide for policy making in overcoming conflicts.
\end{abstract}

Keywords-Model, Resolution, Conflict, Horizontal, Bima

\section{INTRODUCTION}

Horizontal conflict or so-called social conflict, or what is known as conflict, is an enmity and/or physical clash with violence between two or more groups of people that lasts for a certain period of time and has a wide impact resulting in insecurity and social disintegration, thereby disrupting national stability and hampering national development (Article 1 of Law 7/2012). Estimologically, conflict comes from the Latin verb "con" which means together and "fligere" which means collision or collide. In the Latin verb "configere" means "to hit each other" [1].

In the midst of the diversity of ethnic groups, religions, races, and cultures in Indonesia, the horizontal conflicts related to ethnicity, religion, race and between groups often happens. The conflict has become a symptom that worries Indonesian society. This began with several horizontal conflicts which later escalated massively into ethnic conflicts, such as the Sampit riot $(1996,1997,2001)$ - conflict between Dayak and Madurese tribes, the Sambas riot (1999) - conflict between Malays and Dayaks and Madurese, Ambon riots (1999) - conflict between Christian and Muslim communities,
Sampang riot (2012) - attacks on Shia community. The riots that were triggered by ethnicity, religion, race and between groups resulted in significant casualties and material losses. According to a study conducted by the National Information Institute, violence from this horizontal conflict has resulted in more than 2000 deaths and the breakdown of social, political and economic harmony. Even as a result of the many horizontal conflicts in Indonesia, a new term has emerged in the discourse of social science, namely "amoks", which refers to the phenomenon of violence and it is taken from the vocabulary of the Indonesian language "amuk" [2]

Bima Regency is a district in West Nusa Tenggara (hence called WNT) with a population of approximately 488,577 people in 2020. Bima Regency has an area of approximately $4,389 \mathrm{~km}^{2}$ with 18 sub-districts and has 191 villages. This district is located on the eastern side of Sumbawa Island, and the majority of its population is Muslim, with a plural demographic consisting of various ethnicities, namely the Mbojo, Samawa, Minang (Malay), Javanese, Madura, Balinese, Sasak, Makassar, Bugis, Bajo, Flores, and Chinese, Arabic, and others with a dominant number of the Mbojo (Bima) tribe. Bima is known as an area prone to social conflicts, even it is considered the "red zone" in West Nusa Tenggara. In 2012, the Indonesian Forum for the Environment noted that in Indonesia there were 22 areas prone to mining conflicts, conflicts between communities and mining companies, and one of them is Bima (Walhi, 2012) [3].

The Police Chief (at that time Inspector General Pol Nana Sudjana) stated that the WNT region was still prone to social conflicts. Based on the mapping results on several districts and cities in WNT, there are several areas indicating to have have the potential for social conflict vulnerability, such as Bima, Sumbawa, Dompu and Mataram [4]. Conflicts in the form of violence are very common, this can be seen from the distribution of violence that occurred after the reformation [5]. The social conflict that occurred in Bima cannot be separated from the impact of the crisis during the New Order era like those social conflicts occurred in other areas in Indonesia [6].

In Bima, the conflicts that occurred were vertical and horizontal conflicts. Vertical conflicts that occur between the government, the private sector and the community are due to different interests, for example the conversion of land for 
building construction and mining as what happened in 2011 in Lambu Sape and Parado in Bima District. In 2017, there was conflict between villages in Woha District, namely between Risa and Dadibou villages [7]. In addition, there were interfaith conflicts motivated by the worship building construction, conflicts motivated by welfare inequality, conflicts due to poor road infrastructure, road blockages demanding protection of the price of shallots, conflicts due to the clean water crisis, conflicts motivated by law enforcement demands, communal conflicts between villages, and also conflicts between supporters of political parties in general elections.

The horizontal conflict in the Bima community is unique. It is called unique, because sometimes there is no clear and substantive cause and trigger for a conflict. The conflicts could widen and involve large masses of people, without being systematically mobilized. The conflicts in Bima were quite complicated, involving all ages, even children, caused by trivial things, such as liquor drinking and the music performance or festival, but the impact was widespread and destructive, and they often persisted for a long time. The mass mobilization was also very fast and open, meanwhile law enforcement was not implemented optimally.

The study on horizontal conflict in the Bima community is urgent because of some reasons. First, there is no clear and comprehensive picture of the number, characteristics, and causes of the conflict. Second, there is no clear description and mapping of how the conflict pattern occurred. Third, there is no clear picture of the pattern and strategy for policies or conflict resolution. Fourth, the conflicts that occurred did not show any signs of ending, instead they tend to extend and expand, and thus many parties were sacrificed in the conflict. Based on this description, this study is aimed at: a) explaining the typology of horizontal conflict in the Bima community, including the causes and patterns of conflict; and b) formulating a horizontal conflict resolution in the Bima community.

\section{METHOD}

This research is an empirical legal research in which it uses empirical facts taken from human behavior, including verbal behavior obtained from interviews and real behavior gotten from direct observation. Empirical legal research is also used to observe the human behavior in the form of physical remains and archives [8]. Here, law is interpreted as the result of social symptoms, or the result of social interaction patterns. This study was carried out thorough case, conceptual and policy approaches. This study took place in the district of Bima WNT province. Data collection was carried out thorough in-depth interviews with informants - communities experiencing conflict. The purposive sampling technique was applied to select the informants consisting of 5 people in which 3 of them were who experienced conflict, and two others are academician and religious or community leaders who have concerns about horizontal conflicts in Bima. The primary data were obtained from: 1). in-depth and structured interviews with the informants; 2). observations, regarding the horizontal conflicts that often occur in Bima. While the secondary data as the supporting data were obtained from 1). primary law, such as statutory regulations, judge decisions, doctrine, and others. 2) secondary legal materials in the form of references such as books, journals, etc., and, c) tertiary legal materials such as dictionaries and encyclopedias. The data were collected through in-depth interviews and observations. While literature review was carried out reading through various references such as laws and regulations, journals and books and other required data. Data analysis was carried out thorough heuristic, verification, interpretative, descriptive and prescriptive stages.

\section{RESUlT AND DISCUSSION}

Conceptually, conflict is distinguished from violence. Conflict is a relationship between two or more parties (individuals or groups) who have, or those considered to have conflicting goals. Meanwhile, violence includes actions, words and attitudes, structures or systems that cause physical, psychological and environmental damage, and / or prevent people from developing their potential . Dispute is a form of attitude towards differences that does not cause violence, while conflict is a form of attitude towards differences that can cause violence [9]. Because conflict is only a fact of life, conflict is not actually related to issues of good and bad, and the important point is how we manage conflicts. Conflict is a social phenomenon that always occurs in the life of every community and conflict cannot be separated from our lives [10].

The diversity of ethnicities and religions in WNT province tend to cause the intensity of vertical and horizontal social conflicts, open and closed social conflicts [7]. Conflict that ends in violence is actually not strange thing in the social dynamics of the life of the Bima community. The rise of violent conflict is a risk in the early phase of government towards democratic transition, especially when the elites are threatened by political change. Jacques Bertrand considers that the initial period of transition in Indonesia is a critical juncture [5]. The moment of change from an authoritarian regime to a democratic one is very vulnerable to various upheavals, especially within the democratic institution structure that are still fragile.

Other research conducted by Arihan on Conflict between Renda Village and Ngali Village, Belo District, Bima Regency observed the Latent conflict and manifest conflict between Renda Village and Ngali Village. The conflict dielectics between Ngali Village and Renda Village was marked by manifest conflicts as thesa, the latent conflict appears as the antithesis, and the mixture of latent and manifest conflicts as a synthesis, and then a new thesis emerges in the form of a more violent manifest conflict. The social conflicts that took place in Ngali and Renda villages occurred in several periods; First, the conflict in 1909 up to 1911, this communal conflict was due to the influence of revenge for the defeat of the Ngali people against the Dutch. Second, it occurred in 1911 up to 1970 between Ngali village and other villages through the traditional "Ndempa Ndiha" tournament. Third, the conflict between youths using sharp weapons which happened in 1971 up to 1991. Fourth, from 1991 to 2012 , the conflict occurred between villages using homemade firearms, a conflict that caused a lot of victims [11].

\section{A. Factors Causing Conflict in Bima District}

The conflicts in Bima Regency were caused by mining exploration in Bima Regency specifically in Sape and Lambu 
sub-districts and other areas which led to conflicts between groups, even conflicts between community and the government which caused the burning of the police station in Parado, Lambu and burning of the Bima Regent's office. Many people think that conflict is synonymous with violence. This is because a conflict in social reality is always followed by acts of violence, for example the destruction of places of worship, community brawls, fights between groups, burning of public facilities, all of which often cause the loss of the lives of some victims. This illustration often leads people to consider a conflict as a violence or a conflict ends in a violence which causes many victims suffering [12].

The mining-motivated conflict that occurred in Sape and Lambu Subdistricts, in Bima Regency according to KontraS 'records, the violence that occurred on December 24, 2011 and the series of violent acts that occurred afterwards, is one of many violence cases that occurred in Indonesia. As an example, two years after the Sape incident, from January to December 2013, there were one hundred and seventeen cases of violence in the natural resources sector [13]. The form of conflict that occurred in the Sape and Lambu subdistricts was vertical and horizontal conflicts. This is in line with what Irwandi and Endah R. Chotim (2017) stated in their research in which vertical conflicts occur between communities, village government and mining companies. Meanwhile, horizontal conflicts occur within society itself between pro and contra groups.

TABLE I. VICTIMS IN THE CONFLICT IN SAPE AND LAMBU DistRICTS IN 2011

\begin{tabular}{|l|l|l|}
\hline No. & Consequences of Conflict & Number of Victims \\
\hline 1. & Death Victim & 3 people \\
\hline 2. & Victims of gunshot wounds & 36 people \\
\hline 3. & Victim of Persecution & 11 people \\
\hline
\end{tabular}

Furthermore, conflict between religions with the motive of establishing a house of worship in Bima Regency in which the people are $99 \%$ Muslim. In the recent years, the construction of statues for the sake of worship for Hindu people has caused various reactions from the community, such as demonstrations in Bima Regency. In addition, there was also a conflicts between community groups such in the Wane beach area, Monta District, and in Tambora, Bima Regency [14] .

In general, the Bima region is considered prone to vertical and horizontal conflicts. Horizontal conflicts are often triggered by trivial things such as liquor or alcohol drink and the music festival or performance, economic problems, the emergence of communal solidarity for destructive things, and even due to the increasingly distant of the society from religious values. Meanwhile, vertical conflicts occur because of policy problems. The Bima community is easily provoked [15]. Other research conducted by Ahmadin on Inter-Village Social Conflict in Historical Perspective in Bima. The causes of social conflict are: a). juvenile delinquency; b). the tough character of society in which each person has his own character and nature; c). Cultural shift; $d$ ). The performance of local government structures is not optimal and e). The authorities in charge are slow to respond and act.
The main cause of the latent conflict in Renda and Ngali has been formed from the tradition of "ndempa ndiha" (mass fighting) which then forms a form of youth character who feels tough, and has a heroic spirit (Superior) or the like in the community. This case generally tends to be protected and carried out jointly by a group of youth or society as a value of unity or solidarity which binds to protect one another. Although this tradition is deeply rooted in the character of the Bima community, it is strongly bound again by the cultural values of Maja Labo Dahu, namely mutual respect among the community. Respecting the elders has become a tradition that is strongly embedded in the Bima community, especially in the village people of Renda and Ngali. Conflict in the village of Renda and Ngali village is the result of conflict transformation from the ndempa tradition which is defined as the spirit of honesty, openness, and patriotism [6].

Among other aspects that cause the conflict are social inequality and welfare, poor road infrastructure, uneven development that makes the people of Bima react to demand improvements in the form of closing road access by planting banana trees on and also putting soil and stones the street. The demand for the road repair also created divisions among the community which caused quarrel and then lead to horizontal conflicts. Road blocking was also caused by residents who demand protection of the price of shallot agricultural products, such as in Belo and Sape.

The conflicts motivated by the law enforcement demands were caused by the unfair practices of law enforcement agencies which then created a crisis of trust among the community. The weaknesses in law enforcement between the disputed groups also caused the communal conflict resulted in various criminal acts such as murder, theft, persecution. Conflict resolution needs to be carried out in a systematic way before, during and after the conflict in the form of conflict prevention, conflict cessation and post-conflict recovery [16].

\section{B. Conflict Resolution Model}

A research on post-conflict of the Bima community was carried out by Firdaus, with a focus on social change in Lambu Subdistrict, Bima Regency. He concluded that one of the factors causing conflict in the context of the Lambu community is the social change that is happening. Other research examines government policies and local wisdom values related to efforts to resolve land conflicts. The results of the research show that land dispute resolution was dominated by non-litigation settlement patterns, for example peace through negotiation, consensus agreement, and mediation. Thus, the principles of customary law in conflict resolution need to be maintained, preserved and socialized [13].

According to Meliala, if at first the conflict is considered a solution, but the conflict grows out of control and another solution is deemed necessary to be put forward, this can be called the concept of "conflict resolution". There are 4 stages in conflict resolution [17]. The first stage is conflict deescalation, which emphasizes the process of ending violence. The military or security forces will usually do this work. The second stage id negotiations, a more politically oriented settlement step involving conflicting groups. The aim is to encourage the parties to make a negotiation. The third is problem solving approach stage with a more social nuance. 
Rothman described four main components in the problem solving approach stage. The First, each party acknowledges the legitimacy of the other party to initiate communication. The second, each party provides correct information about the ongoing conflict including the causes, traumas that arise, and structural obstacles that may be faced in conflict resolution. The third, the two sides began to look for alternative solutions which lead to create peace. The fourth, problem solving workshops, namely the willingness of the parties to provide a conducive atmosphere for conflict resolution. The fourth, the peace building stage which is cultural and structural. It takes a long time and consistency to create a permanent peace [18].

Meanwhile, the horizontal conflict resolution practice as that happened in Ngali and Renda villages in Bima took several tages. The first, a peaceful agreement was reached through Deliberation and Consensus by upholding the cultural values of "Maja Labo Dahu". The culture of mutual respect which was previously firmly attached to the values of the life of the Bima community. Second, the resolution based on the chronology of event in which the conflict ends automatically when the results of the conflict are balanced, and there is a pressure from the police, however this stage tends to be temporary [19].

In horizontal conflicts that involve the government, such as mining conflicts, in making major decisions, regional government needs to pay attention to the aspirations of the community, so as not to cause rejection of policies from the community which can trigger conflict. In addition, local government needs to conduct socialization, collaborating with sub-district and village officers to restore public confidence in government by taking persuasive approaches so that there is no longer hostility and mutual blame. The local government, security forces, and the community must work together in restoring society stability, so that the Bima community upholds the philosophy of "Maja labo Dahu" which is polite, orderly and has mutual respect.

\section{CONCLUSION}

In general, the Bima region is considered prone to vertical and horizontal conflicts. This area is known as an area prone to social conflicts, this could even be the "red zone" in WNT province. In 2012, Walhi noted that Bima Regency was one of 22 mining areas which prone to conflict. Horizontal conflicts that occurred in Bima were often triggered by trivial things, such as the cause of liquor drinks and the music performance or festival, juvenile delinquency, economic problems, cultural shifts, the emergence of communal solidarity for destructive things, the strong character of society, the performance of local government staff that have not been maximal, the slow actions and responses of the authorities in charge, and also being away from the religious values. Conflict patterns and segments involved in conflict are also increasingly changing and expanding. The implications of this conflict were of course very detrimental to the community, to their property, economic activities, education, social and psychological aspects, and even the conflicts caused casualties and made the development activities hampered.

Conflict resolution is an effort to formulate a solution to the conflict that occurs to reach a mutual agreement that is acceptable to the conflicting parties. Conflict resolution is focused on the source of conflict between two parties, so that they together identify more real issues. In short, it is necessary to undertake conflict resolution efforts such as negotiation, consoliation, mediation and arbitration. The horizontal conflict resolution model that should be proposed is the mixed model, namely by mainstreaming the local tradition such as deliberation and consensus in the spirit of "mbolo ro dampa" by upholding the philosophy value of "maja labo dahu". This is supported by a pattern of optimization of government functions. Local government in handling social conflicts must pay attention to the aspirations and interests of the community.

\section{REFERENCES}

[1] E. Setiadi and U. Kolip, "Pengantar sosiologi politik," 2013, Accessed: May 10, 2021. [Online]. Available: https://www.google.com/books?hl=id\&lr=\&id=cDa2DwAAQBA $\mathrm{J} \&$ oi $=$ fnd $\&$ pg $=\mathrm{PR} 1 \& \mathrm{dq}=$ Elly $+\mathrm{M}+$ Setiadi + dan + Usman + Kolip,$+\mathrm{P}$ engantar+Sosiologi:+Pemahaman+Fakta+dan+Gejala+Permasala haan+Sosial:+Teori,+Applikasi+dan+Pemecahannya\&ots $=5 \mathrm{yRP}$ FoBGto\&sig=CGX07uO6bXactdrNex2avdTjpew.

[2] Surwandono, "Pengantar Sosiologi: Pemahaman Fakta dan Gejala Permasala... - Google Cendekia." https://scholar.google.co.id/scholar?hl=id\&as_sdt=0\%2C5\&q=Pe ngantar+Sosiologi\%3A+Pemahaman+Fakta+dan+Gejala+Permas alahaan+Sosial\%3A+Teori\%2C+Applikasi+dan+Pemecahannya \&btnG $=($ accessed May 10, 2021)

[3] A. D. Astuti, "Implikasi Kebijakan Indonesia dalam Menangani Kasus Pencemaran Lingkungan oleh PT. Freeportterhadap Keamanan Manusia di Mimika Papua," 2018. Accessed: May 09, 2021. [Online]. Available: http://ejournals1.undip.ac.id/index.php/jihiWebsite:http://www.fisip.undip.ac.id

[4] R. A. Ramadhan, "Rimpu and Symbolization of Female Identity in Bima Community," 2018. Accessed: May 10, 2021. [Online]. Available: https://www.atlantis-press.com/proceedings/prasasti$18 / 25899683$

[5] J. Bertrand, "Nationalism and ethnic conflict in Indonesia," 2004, Accessed: May 10, 2021. [Online]. Available: https://www.google.com/books?hl=id\&lr=\&id=2oZQRuT78JIC \&oi=fnd\&pg=PR11\&dq=Jacques+Bertrand,+Nationalism+and+ Ethnic + Conflict+in+Indonesia\&ots $=3$ VyiKIrAuk\&sig=E64n30r my2KcgKfJfzot1R3gtUI.

[6] A. Zuber, B. H.-S. J. S. Pedesaan, and undefined 2018, "Conflict Resolution Between of Renda Villagers and Ngali, Belo Subdistrict, Bima Regency of The Province of West Nusa Tenggara (NTB).” Accessed: May 10, 2021. [Online]. Available: http://journal.ipb.ac.id/index.php/sodality/article/view/23236.

[7] K. Syuhada, "FAKTOR DAN UPAYA RESOLUSI KONFLIK SOSIAL (Kasus Kelurahan Kandai Dua Kecamatan Woja Kabupaten Dompu),” 2019. Accessed: May 10, 2021. [Online]. Available:

http://resiprokal.unram.ac.id/index.php/RESIPROKAL/article/do wnload/13/13.

"A. Mukti Fajar dan Achmad Yulianto, Dualisme Penelitian... Google Cendekia." https://scholar.google.co.id/scholar?hl=id\&as_sdt=0\%2C5\&q=A. + Mukti+Fajar+dan+Achmad+Yulianto\%2C+Dualisme+Penelitia $\mathrm{n}+$ Hukum+Empiris+\%26+Normatif\%2C+Pustaka+Pelajar\%2C+ 
Yogyakarta\%2C+2010.\&btnG= (accessed May 10, 2021).

[9] "Achmad Gunaryo, Konflik dan Pendekatan Terhadapnya Google Cendekia.” https://scholar.google.co.id/scholar?hl=id\&as_sdt=0\%2C5\&q=A chmad+Gunaryo $\% 2 \mathrm{C}+$ Konflik+dan+Pendekatan+Terhadapnya\& btnG $=($ accessed May 10, 2021).

[10] S. ISMAWATI, "KEBIJAKAN DALAM PENANGANAN KERUSUHAN ANTAR ETNIS DI KALIMANTAN BARAT," 1998, Accessed: May 10, 2021. [Online]. Available: http://eprints.undip.ac.id/13287.

[11] D. Swasta et al., “ANALISIS KONFLIK ANTARA MASYARAKAT.” Accessed: May 10, 2021. [Online]. Available: http://journal.uinsgd.ac.id/index.php/jispo/article/view/2414.

[12] Y. Junadi, "Relasi Agama dan Negara: Redefinisi Diskursus Konstitusionalisme di Indonesia,” 2011, Accessed: May 10, 2021. [Online]. Available: https://www.google.com/books?hl=id\&lr=\&id=1FkChaGcKwM $\mathrm{C} \&$ oi=fnd\&pg=PP1\&dq=Diskursus+Konflik+Di+Indonesia\&ots =HiaZQyU6CX\&sig=CIwkC2i2J73FAETSmwagskX-LWE.

[13] T. Sebagai et al., "PERUBAHAN SOSIAL PASCA KONFLIK (Study di Kecamatan Lambu Kabupaten Bima) SOCIAL CHANGES ON POST-CONFLICT (Studies in Lambu District of Bima)," 2014. Accessed: May 10, 2021. [Online]. Available: http://eprints.unm.ac.id/4651/.
S. LAMBU, "Diajukan Sebagai Salah Satu Syarat Untuk Mendapatkan Gelar Sarjana Ilmu Politik Pada Jurusan Ilmu Politik Pemerintahan Fakultas Ilmu Sosial Dan Ilmu Politik Oleh:
SATRIA IMADUDDIN.” Accessed: May 10, 2021. [Online]. Available: https://core.ac.uk/download/pdf/77629387.pdf.

[15] "Bima Membara' Dari Sisi Persoalan dan Tawaran Solusi | Kahaba.net.” https://kahaba.net/opini/5989/bima-membara-darisisi-persoalan-dan-tawaran-solusi.html (accessed May 10, 2021).

[16] M. M.-J. I. M. Education and undefined 2016, "Studi Konflik Sosial di Desa Bugis dan Parangina Kecamatan Sape Kabupaten Bima Tahun 2014," ejournal.mandalanursa.org, 2016, Accessed: May 10, 2021. [Online]. Available: http://ejournal.mandalanursa.org/index.php/JIME/article/view/10 9.

[17] I. Sudama, A. Meliala, ... C. L.-I. R. of, and undefined 2021, "BRIDGING SUSTAINABILITY AND POLICING TO BALINESE ORMAS CONFLICT: AN INTEGRATIVE CONCEPTUAL FRAMEWORK," irhs.ui.ac.id, Accessed: May 10, 2021. [Online]. Available: http://www.irhs.ui.ac.id/index.php/journal/article/view/301.

[18] S. S.-W. J. P. Sosial and undefined 2013, "Revitalisasi Nilai-Nilai Kearifan Lokal Bagi Upaya Resolusi Konflik," journal.walisongo.ac.id, Accessed: May 10, 2021. [Online]. Available:

https://www.journal.walisongo.ac.id/index.php/walisongo/article/ view/235.

[19] "KONFLIK, RESOLUSI KONFLIK DAN KEADILAN ALTERNATIF - PDF Download Gratis.” https://docplayer.info/185612041-Konflik-resolusi-konflik-dankeadilan-alternatif.html (accessed May 10, 2021). 